\title{
Kind-Kovács, Friederike. 2014. Written Here, Published There - How Underground Literature Crossed the Iron Curtain. Budapest: Central European University Press. 520 pp.
}

\section{Reviewed by Miklós Haraszti, Central European University, Budapest}

Friederike Kind-Kovács' monograph is an encyclopedic yet well-structured and insightful account of one of the most surprising last kicks of the Gutenberg era (that is, of the by now foregone, relatively brief period of history when exchange of thoughts via paper-based mechanical multiplication had a crucial effect on culture and politics). Kind-Kovács' subject is the international communication technology of dissident intellectuals and movements in the Soviet Union and the Soviet-dominated Central-European countries in the last decades before the collapse of these regimes and their pervasive censorship systems. She examines the ways dissident writers had their manuscripts smuggled through the Iron Curtain and published in the West, acquire global attention or at least that of their Western colleagues, and finally get both printed copies and the news of their work smuggled back into their countries. These activities bore the name tamizdat, an ironic under-statement abbreviation that in Russian sounds like one of the names of authorized Soviet publishing houses but which literally means "published over there." Tamizdat departed from the samizdat clandestine manuscripts and home-made publications in its persistence upon print publications that remained of course unauthorized and even retaliated, but which still transformed this underground literature into a kind of institutionalized cultural product(ion).

As Kind-Kovács shows, the tamizdat independent literature became possible only thanks to the strategy of getting it published first in the West and then by crude, inefficient homemade, clandestine multiplication. Without the insistence on making the West know about this literature it would have been impossible to defy State censorship and ownership of all means of communications and publication, which lasted well into the era of television broadcasts as well. Kind-Kovács touches upon all the exciting aspects of this unique late Cold-War practice of puncturing the Iron Curtain with words. Her discussions move from the technological aspects of this daring enterprise to its cultural implications, from intellectual achievements to political ones and from civil networking to censorship trials, while weaving all these aspects into a wellmanaged and richly documented research. Thus she manages to retrace and put together the dynamics and impact of a cultural movement that in real time had to be secretive and fragmented. As an erstwhile participant in Hungary's samizdat and tamizdat production I can testify that back then, as we operated through the "fog of underground," we could only dream of having a retrospective overview of our international movement that is as reliable as KindKovács' study.

Written Here, Published There starts by a chapter summarizing the history of the earlier, Soviet tamizdat, which never had the domestic political and social impact that the later, Centraland Eastern-European tamizdat had, especially in Poland, Hungary and Czechoslovakia.

$(\mathrm{cc}) \mathrm{Br}$

ULLS D-Serle 
Tamizdat, that is, smuggling manuscripts out and publishing them abroad, was all that was achievable for independent minds under the strict oppression inside the Soviet Union. In communist Central-Europe tamizdat went further: it was a precursor of a well-organized domestic samizdat production; and even after clandestine publishing of samizdat started, tamizdat remained a part of the movement, through a quite massive smuggling backward of the books published abroad. Despite this difference between tamizdat's role in the Soviet Union proper and its outer empire, as Kind-Kovács explains, the less domestically effective Soviet tamizdat was nevertheless a vital game-changer as the Soviet manuscript smugglers were incomparable moral heroes. They all knew there was no way for them to escape brutal repression. Andrey Sinyavsky, Andrey Amalrik or Alexander Solzhenitsyn wrote and passed their works to the West, thereby practically challenging the State to throw them into one of the world's most cruel prison systems. The moral lesson they taught to the entire Soviet empire and the West included shattering the illusions of world-wide intelligentsia and Western Leftists, inspired by Soviet propaganda itself, about the real nature of this system. The Soviet tamizdat's partly intellectual and partly political impact on the West had significant consequences for the Cold War's evolvement on the level of international politics, comparable to the domestic political changes achieved later by Central-European liberation movements inspired by Polish, Czechoslovak and Hungarian samizdat and tamizdat writers. Put differently, the Soviet tamizdat helped force the moderate human-rights "basket" into the Helsinki Accords of the mid-1970s, while the Central-European tamizdat helped execute the far from obvious potential of those vague provisions.

The second chapter surveys the birth and life of the transnational intellectual networks active in the late Cold-War era that eventually forced both Western and communist governments to pay heed to human right issues as part of their relationships. In dealing with this issue KindKovács traces the activities of local writers, émigrés and Western publishers, all of whom maintained a powerful cooperation fueled by inter-personal friendships, all in the effort to attain international enforcement of freedom of thought in the countries where these writers lived.

The book's third chapter maps the ethical and practical efforts of diplomats working for different governments, or reporters of the Radio Free Europe/Radio Liberty (RFE/RL), to help ideas and literature pierce the "iron pretext." Many accredited Western journalists in the communist countries acted to help tamizdat's function by acting against the rules of their organizations.

At this point I should disclose that I read this book as a reminder of a milieu that is keenly missing from the West's present-day relativist attitude to anti-democratic countries; namely, civil and governmental solidarity with thought-producers in the post-1989 democracies protesting against illiberal tendencies is nowadays far from obvious. As the chapters evolved, I had an intensified feeling that this rich account of the tamizdat story is doubled by the warning that it sends to contemporary civil and political leaders by the very force of its subject matter.

The fourth chapter tells the well documented story of the endeavors of devoted postHelsinki, Western civil-society activists and intellectuals, typically organized around dedicated non-governmental organizations (NGOs) and periodicals, to publicize oppressed and censored Central-European and Soviet thought-production, which by the 1980s grew into politically colored opposition voices and even movements. 
All this makes this book a long awaited inclusive study of a tradition that should serve as a source of inspiration today, when many of the new Eastern- and Central-European democracies pass laws to hinder, ban and criminalize Western support for civil society. These new legal and not only virtual versions of the erstwhile Berlin Wall are nowadays erected by freely elected legislatures and are not opposed in any meaningful way by Western governments or post-ColdWar intergovernmental organizations. As a result, the victims of the present new wave of elimination of civil society's right to be helped by counterparts from abroad multiply by the day in many of the post-Soviet Republics and even in the EU-member Hungary.

Kind-Kovács' account is far from a political-history handbook alone, as its author is likewise a sensitive observer of the ways in which literary canons have changed in communist Eastern-Europe because of tamizdat's revolt against the Soviet-modeled writer unions. She also accounts for tamizdat's influence on Western literary canons by forcing them to keep an open eye on what goes on behind the Iron Curtain, as Tamizdat was the main source of the West's revelation that there was a true and exciting underground production of literature beyond the Iron Curtain.

I highly recommend Friederike Kind-Kovács' Written Here, Published There for a long list of disciplines in and across the humanities, Cold-War history, Russian, post-Soviet, and Central-European studies, political science, and media and communications studies. I also hope that decision makers in diplomacy, as well as international human-rights advocates, will read it in order to get an inspiration from a surprisingly positive outcome of the cursed time of the Cold War. 